\title{
The Mediating Role of Work-Health Balance in the Relationship between Perceived Work Ability and Affective Job Satisfaction
}

\author{
José-María Figueredo ${ }^{1}$, Cristina García-Ael ${ }^{2}$, \\ Andrea Gragnano $^{3}$, and Gabriela Topa ${ }^{2}$ \\ ${ }^{1}$ National Distance Education University UNED, International Doctorate School, \\ Madrid, Spain \\ ${ }^{2}$ National Distance Education University UNED, \\ Department of Social and Organizational Psychology, Madrid, Spain \\ ${ }^{3}$ University of Milano-Bicocca, Department of Psychology, Milan, Italy
}

\begin{abstract}
The rising age of retirement may result in a larger number of workers with health problems. This is important since health is a key element in all aspects of life, including work. Although much research has been carried out into how work-life balance influences occupational health, very few studies have focused on how the ability to balance health needs and work demands (work-health balance) affects different organizational variables such as perceived work ability and affective job satisfaction. In a context in that the age of retirement is constantly rising, it is vital to explore those factors may help extend people's working life in a balanced manner. The aim of this study was, therefore, to explore the mediating role of work-health balance in the relationship between perceived work ability (physical and mental) and affective job satisfaction. Using a cross-sectional sample of 294 workers aged 39 years and over, the study analysed the mediating role of the different dimensions of work-health balance (health climate, work-health incompatibility and external support) in the relationship between work ability (physical and mental) and affective job satisfaction. The data suggest that the health climate and work-health incompatibility dimensions mediate the relationship between work ability (physical and mental) and affective job satisfaction. Our findings are consistent with the current understanding of the role played by the balance between occupational health and the well-being of older workers.
\end{abstract}

Keywords: work-health balance, perceived work ability, affective job satisfaction, work retention, older workers

José-María Figueredo, National Distance Education University UNED, International Doctorate School, Calle Bravo Murillo, 38, 3º, 28015, Madrid, Spain. E-mail: jfiguered4@alumno.uned.es 


\section{Introduction}

The increase in the incidence of chronic illness due to unhealthy lifestyles, coupled with the rising retirement age in developed countries (World Health Organization [WHO], 2002), is gradually transforming the labour market, increasing the proportion of workers with health problems owing either to the natural ageing process or to chronic serious illnesses (European Statistical Office [Eurostat], 2011). This situation poses a challenge for organizations, that must strive to balance the health needs of their employees with the demands of the jobs they perform.

Health is one of the domains of life that interacts with the work domain (Keeney et al., 2013), and is, therefore, a key aspect to take into consideration when analysing work-life balance. To date, much research has been carried out on work-life balance, finding (among other things) that it is related to affective job satisfaction, which in turn positively influences other aspects of work, such as perceived work ability (Marqueze \& de Castro, 2009; Martínez et al., 2004; Puigmitja et al., 2019; Silva et al., 2012), employee performance and the attainment of organizational goals (Cantarelli et al., 2016; Saber, 2014), and is negatively associated with employee turnover (Carsten \& Spector, 1897; Hochwarter et al., 1999; Judge et al., 2001; Randall \& Scott, 1988; Shore \& Martin, 1989; Sullivan \& Bhagat, 1992). However, these studies almost never include worker perception of work-health balance issues. Work-health balance is a recently emerged concept (Miglioretti \& Gragnano, 2016) that refers to workers' perception of the compatibility of work and health, and of the work environment as a place that responds to their health-related needs.

Given that little research has focused on how this recent construct is related to other organizational variables such as perceived work ability and affective job satisfaction, the aim of this study was to explore these associations among a sample of older workers.

\section{From Work-Life Balance to Work-Health Balance}

The work-life balance construct has been defined in many different ways. Kalliath and Brough (2008) tried to unify them by defining the concept as the individual perception that work and non-work activities are compatible and promote growth in accordance with an individual's current life priorities. The last part of this definition highlights the existence of different life domains, and the fact that these may differ, not only from person to person, but even in the same individual depending on their current priorities. Keeney et al. (2013) identified eight life domains that interact with the work domain and contribute to establishing a person's identity, health being one of them. For instance, under certain circumstances, a worker may feel that the demands of their job are incompatible with their health needs. This in turn would prevent them from having a positive work experience and would also hamper their personal growth. Different studies have shown that striking 
a good balance between work and life is associated with lower levels of psychological strain, anxiety and depression (Fisher et al., 2009; Grant-Vallone \& Ensher, 2001), as well as with higher levels of affective job satisfaction, greater organizational commitment, less job pressure and lower intention to switch jobs (Huffman et al., 2008; Hughes \& Parkes, 2007; Lingard et al., 2007; O'Driscoll et al., 1992; Siegel et al., 2005). Despite this, however, the instruments which assess work-life balance almost never include aspects linked to health. This is the context in which the work-health balance construct emerged (Gragnano et al., 2017).

\section{Work-Health Balance}

Miglioretti and Gragnano (2016) defined this construct as a state in which workers feel able to efficiently balance health needs and work demands. It takes two aspects into account: perception of compatibility between personal health situation and job characteristics; and perception of the effort made by the work environment to satisfy employees' health needs. Thus, work-health balance comprises two dimensions: a) Perception of compatibility between work and health; and b) Perception of the willingness of the work environment to respond to individual health needs. The first (intrinsic) dimension refers to an assessment of one's ability to cope with the demands of one's job in light of one's health needs. The second (extrinsic) dimension alludes to an assessment of what one's work environment is willing to do to satisfy employees' health needs. This dimension includes (among other aspects) the perception of job flexibility, support from one's direct supervisor and level of attention paid by management to employee health.

The first dimension was operationalized as Work and Health Incompatibility (WHI), an assessment of the extent to which current work activities hamper the management of personal health needs. The second dimension was operationalized through two constructs: health climate, and external support (Gragnano et al., 2017). According to Gragnano et al. (2017), work-health balance is a dimension that exists among all workers.

Since this is a recent construct, few studies have been conducted to date on this issue. Nevertheless, working with a sample of older railway employees, Gragnano et al. (2018) identified five different profiles linked to work-health balance, observing differences between groups of workers with significantly different scores for variables associated with health and well-being at work. These profiles were: extreme unbalance, moderate unbalance, extreme balance, moderate balance, and difficulties with resources. They also studied the distribution of each profile in terms of gender, job role and presence of long-standing health problems, finding more women in the two unbalance profiles and more men in the moderate balance profile. In regard to job role, white-collar workers tended to be located more in the extreme unbalance profile and less in the moderate balance one, and blue-collar workers more 
in the moderate balance profile. Workers with long-standing health problems were located in the two unbalance profiles and the difficulty with resources profile.

Working with a sample of 525 Italian workers, Miglioretti and Gragnano (2017) found that work-health balance differed across different groups of workers (healthy workers/workers with long-standing health problems; men/women; older workers/younger workers). Moreover, they also found a negative relationship between work-health balance and presenteeism, as well as a positive one between work-health balance, performance, and perceived state of health.

The results of the previous studies provided evidence of the importance of the balance between work and health in the lives of workers, supporting the adoption of the WHB concept. In a recent study, the WHB explained more variance than workfamily balance in the level of affective job satisfaction among 318 workers (Gragnano et al., 2020).

Other investigations, in which the WHB construct is not directly examined, but other variables that could be related, such as perceived organizational support, direct supervisor support or work flexibility, show that these variables have a direct effect and positive on affective job satisfaction (Johnson \& Johnson, 2020; Li et al., 2020; Winoto et al., 2021). In turn, affective job satisfaction had a direct and positive effect on employee retention ( $\mathrm{Li}$ et al., 2020; Winoto et al, 2021). On the other hand, systematic reviews of the literature show that supervisor support is related to a higher level of job well-being after returning to work after an illness (Figueredo et al., 2020), particularly in the case of older workers (Söderbacka et al., 2020).

\section{Affective Job Satisfaction}

Job satisfaction is the most widely-researched construct in organizational psychology. Despite this, however, there is still no consensus regarding its structure (Judge et al., 2017), although there is currently a general trend towards distinguishing between affective and cognitive job satisfaction.

Affective job satisfaction is defined as a positive global emotional response to work in general (Moorman, 1993), and is often considered synonymous with general job satisfaction. For its part, cognitive job satisfaction is assessed by means of rational comparison of work conditions with a desired or expected standard (Locke, 1969; Moorman, 1993; Spector, 1997).

Diverse studies have confirmed the influence of affective job satisfaction on other aspects of work, such as individual job performance and the achievement of organizational goals (Cantarelli et al., 2016; Saber, 2014). For their part, Sharkey and Caska (2020) concluded that offering job flexibility improved affective job satisfaction.

The little research that has been carried out on work-health balance has found that high scores in this construct are associated with lower levels of presenteeism, emotional exhaustion, workaholism, and psychological distress, and with higher 
levels of affective job satisfaction and work engagement (Gragnano et al., 2017, 2020). Previtali et al. (2018) assessed the impact of work-health balance on ageing blue-collar employees (over 50) working in the steel industry, confirming that said balance, alongside emotional exhaustion, mediated between job demands and both affective job satisfaction and presenteeism. They also found that work-health balance, alongside work engagement, mediated between job resources and both affective job satisfaction and presenteeism.

\section{Perceived Work Ability}

Work ability is defined as the result of the combined assessment of physical abilities and cognitive abilities in relation to the intellectual or physical demands of the task being performed (Tuomi et al., 1998). Work ability is mainly a question of balance between job demands (physical and/or mental) and personal resources (Ilmarinen, 2005). More recently, McGonagle et al. (2015) defined it as an individual's self-perception or assessment of their ability to continue working in their job. Morschhäuser and Sochert (2006) argue that perceived work ability depends on the psychophysical demands of the job and the individual's state of health and physical and mental capabilities. It also depends on various factors linked to the individual and the workplace (e.g. general conditions in the company, objective working conditions, social environment, individual training and competencies and individual state of health, both physical and mental). Thus, an alteration in the worker's health and functional capacity may have a negative impact on their perceived work ability (Díaz-Bethencourt \& Prieto-Morales, 2016). In general, perceived mental work ability can be defined as an individual's self-assessment of their mental capabilities for coping with the psychological demands of their job. Similarly, perceived physical work ability refers to an individual's self-assessment of their physical capabilities for coping with the physical demands of their job.

Different studies have highlighted the relationship between perceived physical and mental work ability and the affective job satisfaction (Marqueze \& de Castro, 2009; Martínez \& Latorre, 2006; Martínez et al., 2004; Silva et al., 2012), although this relationship has still not been widely studied.

Marqueze and de Castro (2009) conducted a correlational study with university professors and found that high levels of perceived work ability were positively correlated with high levels of affective job satisfaction. Similarly, Martínez et al. (2004) and Martínez and Latorre (2006) found positive correlations between perceived ability for work and affective job satisfaction in a sample of white-collar workers, regardless of sociodemographic variables.

Silva et al. (2012), in addition to demonstrating the positive association between both variables using a sample of shift workers from control rooms, carried out a linear regression analysis and demonstrated that for each point of increase in the work ability score, there was, on average, a one-point increase in the affective job 
satisfaction score. Rahsa et al. (2020), and Pinayungan Dongoran et al. (2020) in studies to examine the influence of leadership style, and perceived ability to work on affective job satisfaction, concluded that each of these variables, both individually and simultaneously, have a significant effect on affective job satisfaction. On the other hand, Trifoglio (2018), using a sample of elderly nurses, aged between 50 and 69 years, and in order to examine the associations between perceived ability for work, affective job satisfaction, work engagement and intention to continue working until retirement, concluded that perceived ability for work was positively related to affective job satisfaction. In turn, affective job satisfaction was positively related to the intention to continue working until retirement age. Both Rasha et al. (2020) and Trifoglio (2018) and Pinayungan Dongoran et al. (2020) used correlation analysis and regression analysis.

It has also been found that perceived work ability among older employees predicts early retirement, with those with poor perceived work ability being more likely to try and access this option (Boissonneault \& De Beer, 2018).

\section{The Present Study}

The general aim of the present study was to explore the relationships which exist between perceived work ability (physical and mental), affective job satisfaction and work-health balance in a sample of workers aged between 39 and 69 years. Analysing these relationships (which include the work-health dimension) is particularly important in light of several well-documented facts. Firstly, the European Union (EU) has confirmed the rise in retirement age among workers in developed countries, populations with a high rate of disability and health problems, particularly among older workers aged between 55 and 64 (20\%) (Eurostat, 2011). Secondly, there has been a drastic improvement in early diagnoses and the medical treatments available for certain serious illnesses, thereby increasing patient survival rates and improving survivors' quality of life (Prins, 2013). Consequently, today, organizations must respond to this situation by providing an adequate balance between the health needs of their employees and the demands of the jobs they perform. In this context, it is vital to explore how to improve the affective job satisfaction of these workers, for whom health is a priority dimension. Given that the ageing of the population puts pressure on developed societies, not only due to the need for labour but also as a result of increased healthcare costs, exploring the balance between work and health and its relationship with employee's well-being is a relevant undertaking.

Finally, from an empirical perspective, to date, only one study has analysed the relationships between work ability (physical and mental), affective job satisfaction and work-health balance (Gragnano et al., 2020). Nevertheless, we believe that, since health is one of the domains of life that interacts with work (Keeney et al., 2013), a change in health status would also impact work-life balance, which, in turn, would 
prevent employees from having a good work experience and hamper their personal growth. We also believe it would have a negative impact on affective job satisfaction. Furthermore, given that work-health balance itself is associated with higher levels of affective job satisfaction (Gragnano et al., 2017; Gragnano et al., 2020), an alteration in health would most likely have a negative impact on this variable. In light of the above, and based on our review of the literature, we posited the following hypotheses:

Hypothesis 1: Perceived physical (H1a) and mental (H1b) work ability will be directly and positively associated with affective job satisfaction.

Hypothesis 2: Perceived physical work ability will be negatively associated with work-health incompatibility $(\mathrm{H} 2 \mathrm{a})$ and positively associated with health climate (H2b) and external support (H2c).

Hypothesis 3: Perceived mental work ability will be negatively associated with work-health incompatibility (H3a) and positively associated with health climate $(\mathrm{H} 3 \mathrm{~b})$ and external support $(\mathrm{H} 3 \mathrm{c})$.

Hypothesis 4: Affective job satisfaction will be negatively associated with work-health incompatibility (H4a) and positively associated with health climate $(\mathrm{H} 4 \mathrm{~b})$ and external support $(\mathrm{H} 4 \mathrm{c})$.

Hypothesis 5a: Work-health incompatibility, health climate and external support will mediate the relationship between perceived physical (H5a) and mental (H5b) work ability and affective job satisfaction. (See Figure 1. General Mediation Model).

\section{Figure 1}

\section{General Mediation Model}
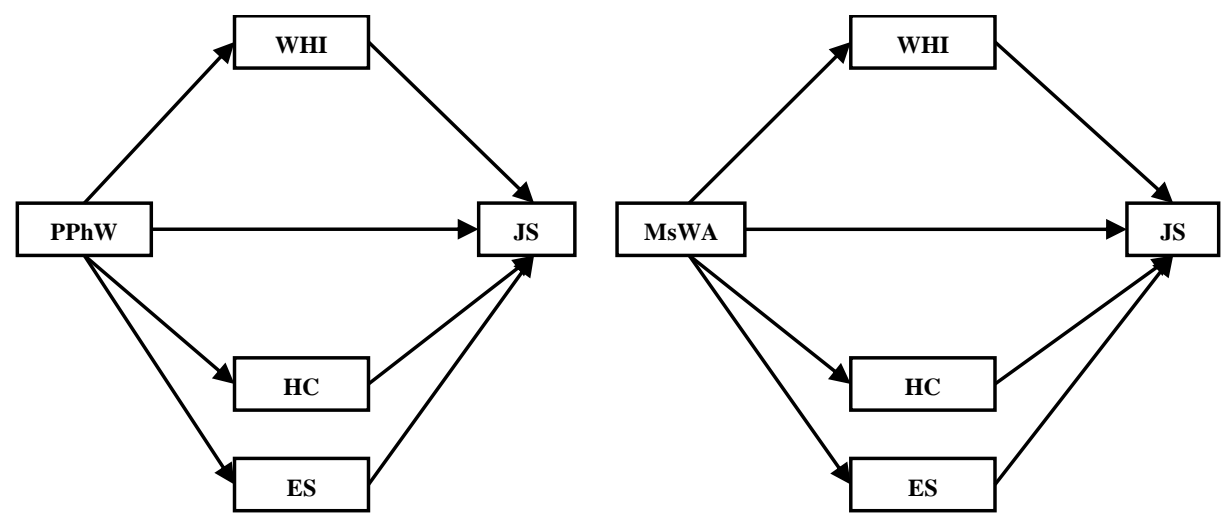

Note. WHI = Work-health incompatibility; $\mathrm{HC}=$ Health climate; $\mathrm{ES}=$ External support; PPhWA = Perceived physical work ability; MsWA = Perceived mental work ability; JS = Affective job satisfaction . 


\section{Method}

\section{Participants}

The sample comprised of 294 workers $\left(n_{\text {women }}=187 ; 63.6 \%\right.$ ), aged between 39 and 69 years $(M=49.90 ; S D=7.045)$. The mean time for which participants had been working for their current employer was 17.6 years.

In terms of professional capacity, $126(42.9 \%)$ were technical staff, 79 (26.9\%) middle management, 32 management (10.9\%) and 8 (2.7\%) unskilled workers. The remaining participants $(16.6 \%)$ claimed to belong to other professional categories not included on the list provided. The majority of participants worked for private companies $\left(n_{\text {private }}=161 ; 54.8 \%\right)$ and the rest worked for the public administration $(45.2 \%)$. In regard to professional field, $120(40.8 \%)$ worked in either the education or research sector, $27(9.2 \%)$ in industry, $14(4.8 \%)$ in banking or finance, and the rest (45.2\%) in other professional sectors. In terms of the size of their organizations, 157 (53\%) worked in companies with over 200 employees, 66 (22.4\%) in companies with between 50 and 199 employees, 44 (15\%) in companies with between 10 and 49 employees and 27 (9.2\%) in companies with up to 9 employees. Moreover, 250 (85\%) worked full time and $33(11.2 \%)$ part time, with the rest (3.8\%) being unemployed and actively searching for a job at the time the questionnaires were administered. Finally, most participants had undergraduate or advanced engineering qualification $(n=144 ; 49 \%)$ or university diplomas $(n=70 ; 23.8 \%)$. The rest had vocational training $(n=25 ; 8.5 \%)$, Baccalaureate (A-level equivalent) $(n=18 ; 6.1 \%)$ or basic secondary school qualifications $(n=1 ; 0.3 \%)$ or claimed to have qualifications not included on the list provided $(n=36 ; 12.3 \%)$.

\section{Instruments}

In order to test our hypotheses, we asked participants a series of questions about their perceived occupational health, work ability (physical and mental) and affective job satisfaction.

To measure work-health balance, we used the Work-Health Balance Questionnaire (WHBq, Gragnano et al., 2017). This instrument comprises 17 items that measure three dimensions: a) Work-health incompatibility (WHI); b) Health Climate (HC); and c) External Support (ES). The work-health incompatibility scale comprises six items and refers to the worker's perception regarding whether or not the demands of their job are incompatible with their health needs (e.g. Your job is a hindrance to your health). The health climate scale comprises five items that refer to the worker's perception of whether or not management is concerned about employee health (e.g. Senior management acts decisively when concerns about health emerge between employees). Finally, the external support scale, that comprises six items, refers to schedule flexibility and support from supervisors or superiors regarding 
health needs (e.g. It is O.K. with your employer if you work at home for health reasons). Responses are given on a Likert-type scale ranging from 1 (strongly disagree) to 5 (strongly agree). The reliability coefficient was high $\left(\alpha_{\mathrm{WHI}}=.85 ; \alpha_{\mathrm{HC}}\right.$ $\left.=.90 ; \alpha_{\mathrm{ES}}=.80\right)$.

To measure affective job satisfaction, we used the Brief Index of Affective Job Satisfaction (BIAJS) by Thompson and Phua (2012), translated and validated in Spanish by Fernández-Muñoz and Topa (2018). The BIAJS is one of the instruments that has been used most over the last decade to measure affective job satisfaction (Hurtado et al., 2017; Kottwitz et al., 2017). It is a brief scale that measures this construct by means of a single factor comprising four items: "I find real enjoyment in my job", "I like my job better than the average person", "Most days I am enthusiastic about my job" and "I feel fairly well satisfied with my job". The Spanish version of the scale has adequate psychometric properties and can be considered a valid and reliable instrument for assessing the affective satisfaction of older employees with their job (Fernández-Muñoz \& Topa, 2018). Responses are given on a five-point Likert-type scale ranging from 1 (strongly disagree) a 5 (strongly agree). Fernández-Muñoz and Topa (2018) reported a Cronbach's Alpha value of $\alpha=.83$. Our results in this study were similar $(\alpha=.89)$.

Perceived work ability was measured using the validated Spanish version (Peralta et al., 2012) of the Work Ability Index (WAI, Tuomi et al., 1998). In both clinical practice and research, the WAI is the most-used instrument in the field of occupational health and its validity and reliability have been evaluated by many different studies (De Zwart et al., 2002; Mateo-Rodríguez et al., 2019; Peralta et al., 2012; Radkiewicz \& Widerszal-Bazyl, 2005). The WAI is a questionnaire comprising 10 items grouped into seven dimensions: 1) current work ability compared with lifetime best; 2) work ability in relation to the demands of the job,that comprises two items linked to physical and mental resources; 3) number of current diseases diagnosed by a physician (list of 15 diseases); 4) estimated work impairment due to diseases; 5) sick leave during the past year; 6) own prognosis of work ability 2 years from now; and 7) mental resources, measured through items linked to an assessment of ability to enjoy daily activities, being active and alert and feeling hope for the future. As in other studies (Alcover \& Topa, 2018), for the purposes of our research we only used the items linked to physical ("How would you rate your current work ability concerning the physical demands of your job") and mental resources ("How would you rate your current work ability concerning the psychological demands of your job"), since our aim was to focus on workers' mental and physical work ability. The response scale ranged from 1 "(very poor) to 5 (very good)". 


\section{Procedure}

The sample was recruited using nonprobability sampling and the questionnaire was administered online. Participants were contacted by email, informed of the study aims and assured that the data collected would be completely anonymous. After giving their consent to take part in the study, participants completed the different scales of the questionnaire (WHBq, BIAJS and WAI) individually. Participation was voluntary and no reward was offered for taking part in the study. The study received approval from the UNED Ethics Committee and has been performed in accordance with the ethical standards of the Declaration of Helsinki. Participants in the final sample consented to participate in the study, and they could withdraw from the study whenever they wanted.

\section{Data Analysis}

First the descriptive and correlation analyses were carried out using the SPSS 22 software package. Next, a mediation analysis was performed to confirm the direct association between perceived work ability (physical and mental) and affective job satisfaction (Hypotheses 1a and $1 \mathrm{~b}$ ) and the three dimensions of work-health balance (Hypotheses 2a, 2b, 2c, and 3a, 3b and 3c), as well as between the three dimensions of work-health balance and affective job satisfaction (Hypotheses $4 a, 4 b$ and $4 c$ ) and the indirect effects of the three dimensions of work-health balance on the relationship between perceived work ability (physical and mental) and affective job satisfaction (Hypotheses 5a and 5b).

To determine whether the three dimensions of work-health balance (health climate, external support, and work-health incompatibility) mediated the relationship between perceived work ability (physical and mental) and affective job satisfaction, two mediation analyses (model 4) were carried out using the Process macro for SPSS (Hayes, 2009). The bootstrapping technique with 5,000 subsamples was used to estimate the confidence interval $(95 \%)$. This macro provides estimates of the indirect effects of multiple mediators, along with standard errors $(S E)$ and confidence intervals (CI). The technique used is bootstrapping, a non-parametric re-sampling procedure that does not impose an assumption of normality on the sample distribution. Indirect effects are considered statistically significant if the confidence intervals (CI of 95\%) do not contain zero (Hayes \& Preacher, 2013).

\section{Results}

\section{Descriptive and Correlation Analyses}

First, bivariate correlation analyses were conducted to determine the relationship between the variables. In all cases, the assumptions of independence, 
collinearity and homoscedasticity were met. The $V I F$ value $\left(V I F_{\text {mental }}=1.5\right.$ and $\left.V I F_{\text {physical }}=1.5\right)$ was lower than 5 and the tolerance index $\left(T O L_{\text {mental }}=.66\right.$ and $\left.T O L_{\text {physical }}=.66\right)$ higher than 0.2 in all cases, meaning that our data confirm the assumption of noncollinearity between variables (Myers, 1990).

As shown in Table 1, affective job satisfaction was directly and positively associated with both perceived mental work ability $(r=.34)$ and perceived physical work ability $(r=.34)$. Perceived physical and mental work ability were negatively associated with work-health incompatibility $\left(r_{\text {physical }}=-.25 ; r_{\text {mental }}=-.18\right)$ and positively associated with health climate $\left(r_{\text {physical }}=.16 ; r_{\text {mental }}=.06\right)$ and external support $\left(r_{\text {physical }}=.24 ; r_{\text {mental }}=.07\right)$. Finally, affective job satisfaction was negatively associated with work-health incompatibility $(r=-.29)$ and positively associated with health climate $(r=.29)$ and external support $(r=.28)$.

\section{Table 1}

Descriptive Statistics and Correlations between Perceived Physical Work Ability, Perceived Mental Work Ability, Job Satisfaction, Work-Health Incompatibility, Health Climate, and External Support

\begin{tabular}{lccccccc}
\hline Variables & $M$ & $S D$ & 1. & 2. & 3. & 4. & 5. \\
\hline $\begin{array}{l}\text { 1. Perceived physical work } \\
\quad \text { ability }\end{array}$ & 4.07 & 0.78 & 1 & & & & \\
$\begin{array}{l}\text { 2. Perceived mental work } \\
\quad \text { ability }\end{array}$ & 4.04 & 0.70 & $.58^{* *}$ & 1 & & & \\
$\begin{array}{l}\text { 3. Job satisfaction } \\
\text { 4. Work-health }\end{array}$ & 3.62 & 0.86 & $.34^{* *}$ & $.34^{* *}$ & 1 & & \\
$\quad$ incompatibility & 2.49 & 0.90 & $-.25^{* *}$ & $-.18^{* *}$ & $-.29^{* *}$ & 1 & \\
$\begin{array}{l}\text { 5. Health climate } \\
\text { 6. External support }\end{array}$ & 2.85 & 1.04 & $.16^{* *}$ & .06 & $.29^{* *}$ & $-.33^{* *}$ & 1 \\
\hline
\end{tabular}
${ }^{*} p<.05 ;{ }^{* *} p<.01 ;{ }^{* * *} p<.001$.

\section{Mediation Analyses}

As shown in Figure 2 and in Table 2, the results regarding the mediating effect of the three dimensions of work-health balance on the relationship between physical work ability and affective job satisfaction revealed a significant direct association between perceived physical work ability and affective job satisfaction $(\beta=.34, S E=$ $.06, p<.001 ; 95 \%$ CI [.16 .40]). The effects of perceived physical work ability on the three mediating variables were significant in all cases. However, the effects of the three mediating variables on affective job satisfaction were only significant in the case of health climate and work-health incompatibility. In the analysis of the global model, the indirect effect of physical work ability on affective job satisfaction was found to be significant in the case of work-health incompatibility and health climate, indicating a partial mediating effect. 


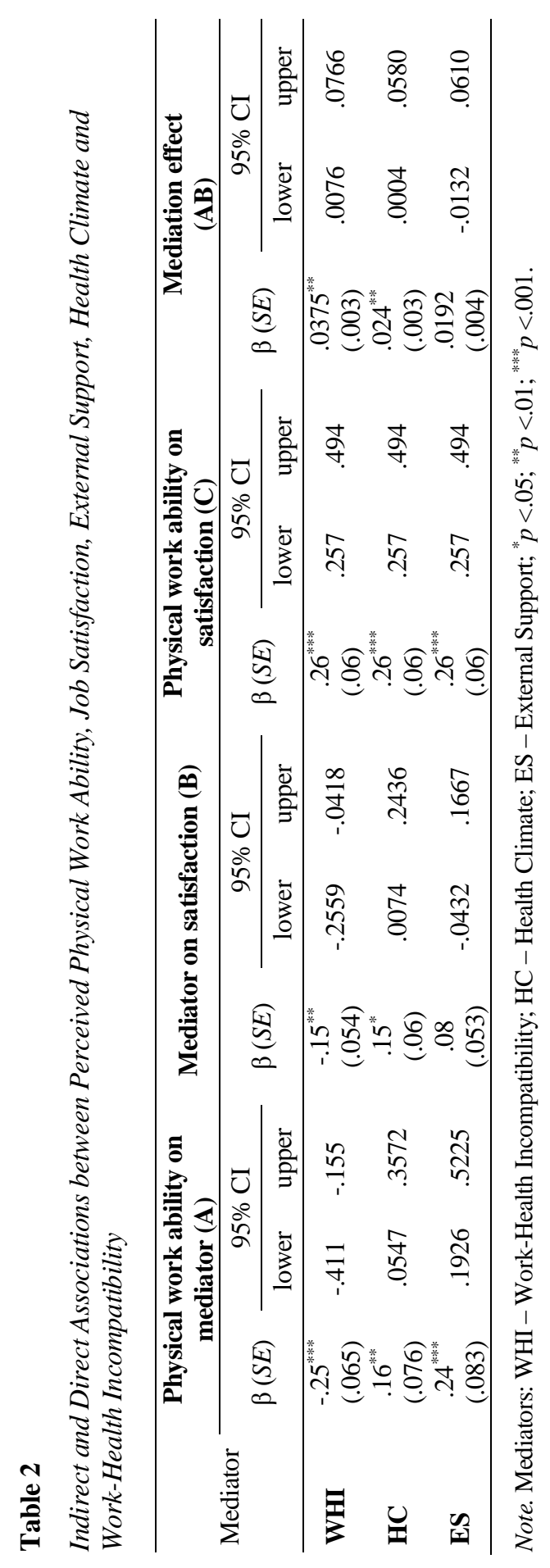


In sum, as shown in Table 2, the results confirm our hypotheses (H1a, H2a, b, and c, $\mathrm{H} 4 \mathrm{a}$ and b). Moreover, hypothesis $\mathrm{H} 4 \mathrm{c}$ was party fulfilled. WHI and $\mathrm{HC}$ were found to mediate the relationship between perceived physical work ability and affective job satisfaction.

\section{Figure 2}

Relationship between Perceived Physical Work Ability and Job Satisfaction

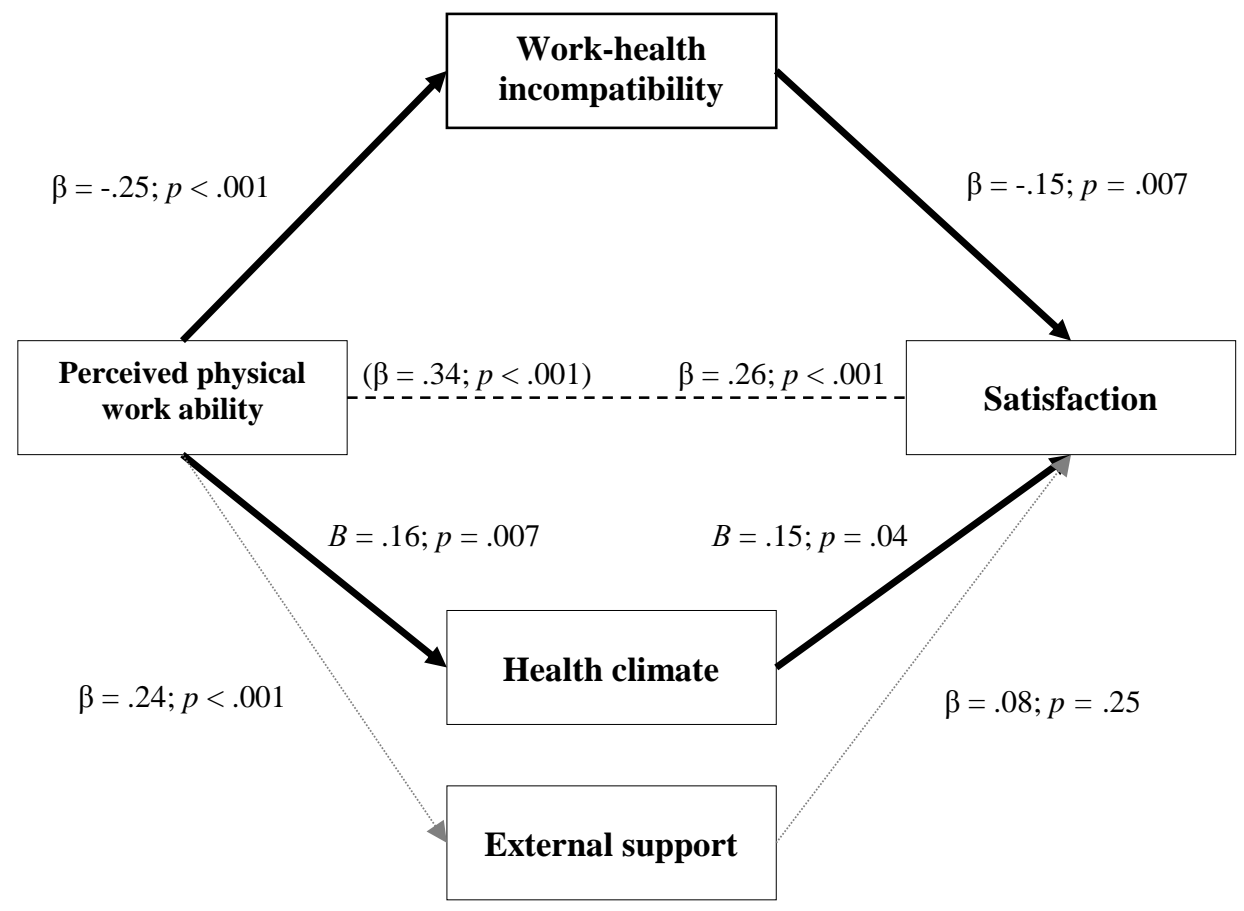

Note. Thicker lines indicate significant relationships $(p<.05)$.

As shown in Figure 3 and in Table 3, the results regarding the mediating effect of the three dimensions of work-health balance on the relationship between mental work ability and affective job satisfaction revealed a significant direct association between perceived mental work ability and affective job satisfaction $(\beta=.34, S E=$ $.07, p<.001 ; 95 \%$ CI $[.29, .55])$. The effects of perceived mental work ability on the three mediating variables were only significant in the case of work-health incompatibility. Similarly, the effects of the three mediating variables on the relationship between perceived mental work ability and affective job satisfaction were only significant in the case of health climate and work-health incompatibility. 


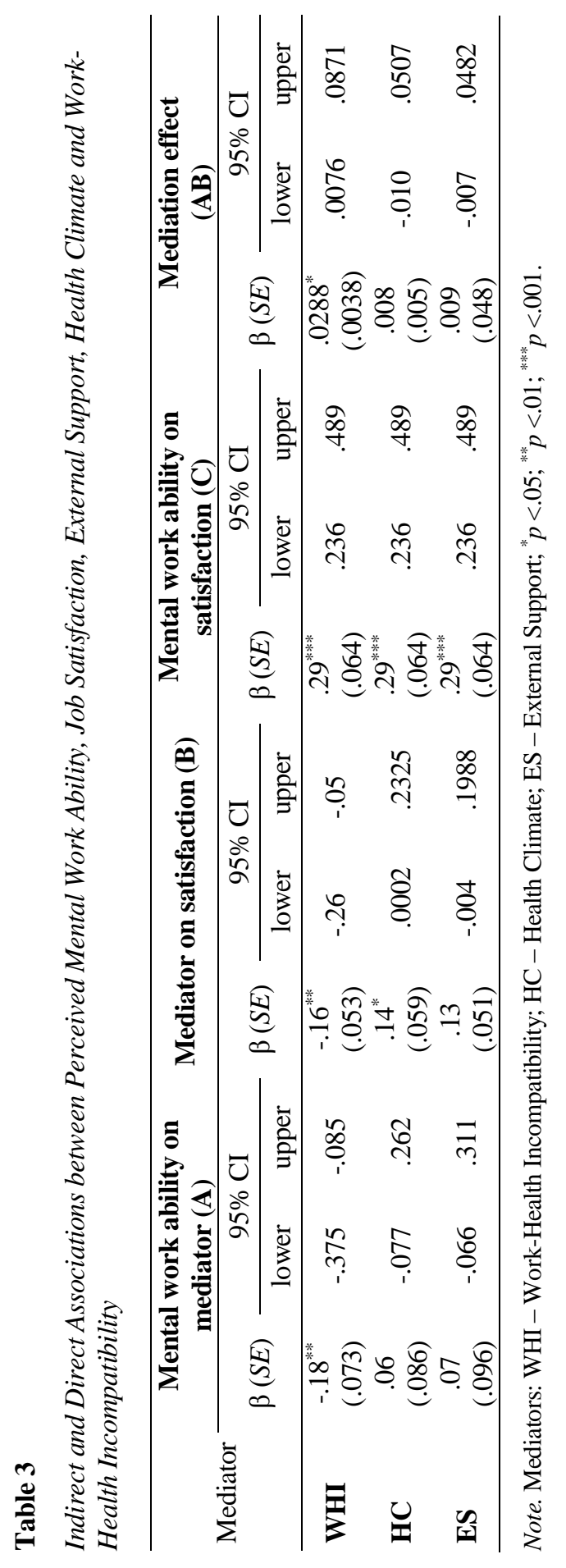


In the analysis of the global model, the indirect effect of perceived mental work ability on affective job satisfaction was found to be significant in the case of workhealth incompatibility, indicating a partial mediating effect. In sum, as shown in table 3 , the results partially confirm our hypothesis ( $\mathrm{H} 1 \mathrm{~b}$ and $\mathrm{H} 3 \mathrm{a}$ ). WHI was found to mediate the relationship between perceived mental work ability and affective job satisfaction.

\section{Figure 3}

Relationship between Perceived Mental Work Ability and Job Satisfaction

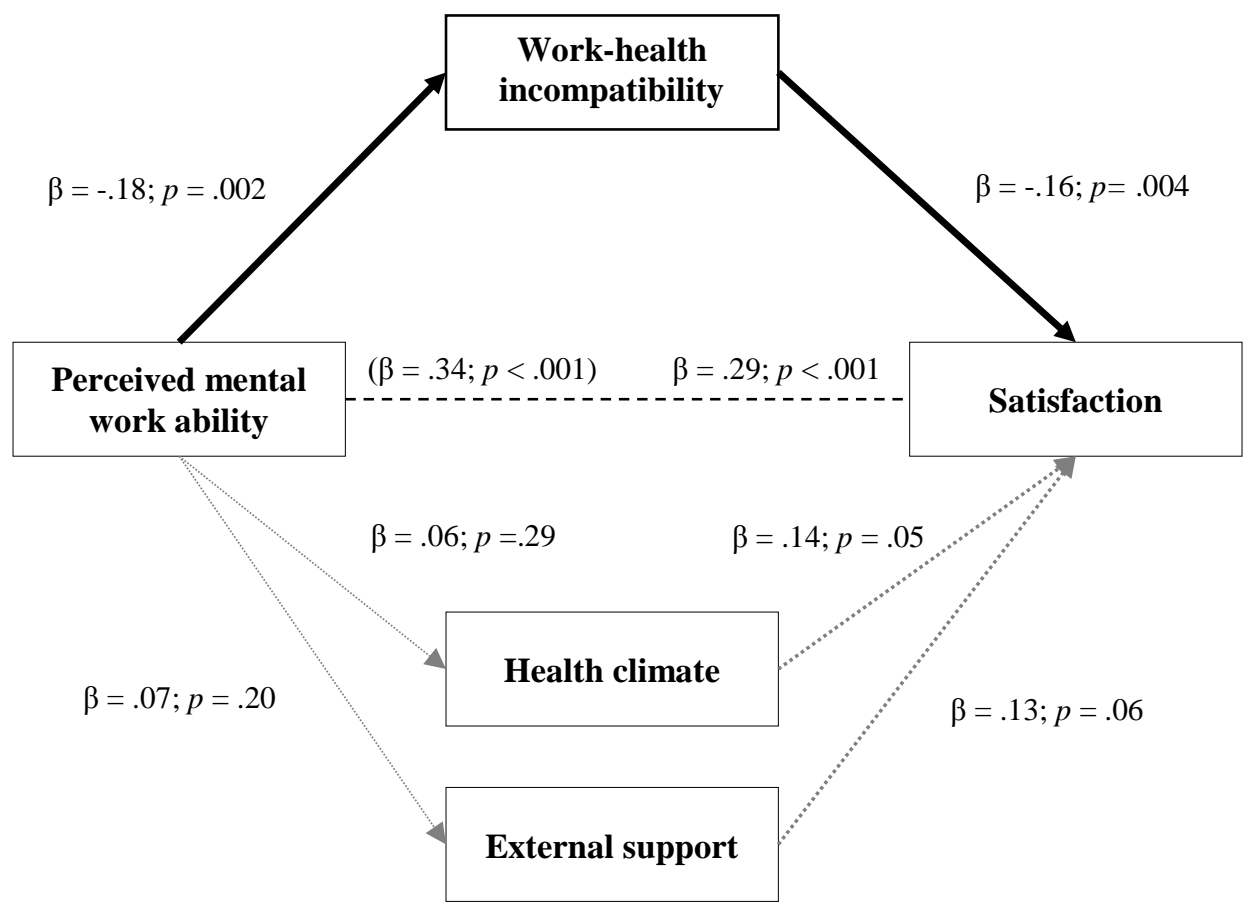

Note. Thicker lines indicate significant relationships $(p<.05)$.

\section{Discussion}

The general aim of our study was to explore the relationships that exist between perceived work ability (physical and mental), work-health balance and affective job satisfaction. Our results confirm that WHI and HC mediate the relationship between perceived physical and mental work ability and affective job satisfaction. These results support the idea of considering the WHB as important for the well-being of all workers and not only among those with chronic health conditions (Gragnano et 
al., 2020). Therefore, our results confirm that perceived work capacity is an antecedent of affective job satisfaction in the healthy working population, and this relationship is also mediated by the worker's perception of the compatibility between their health care and the requirements of their work and their perception about the interest that their superiors showed for their health.

They also confirm a direct effect between perceived physical and mental work ability and affective job satisfaction, thereby confirming our first hypothesis. These findings are consistent with those reported by previous studies that also observed a clear association between perceived work ability and affective job satisfaction (Marqueze \& de Castro-Moreno, 2009; Martínez et al., 2004; Pinayungan Dongoran et al., 2020; Rahsa et al., 2020; Silva et al., 2012; Trifoglio, 2018). This implies that a worker who perceives himself as more capable to carry out his work will also be more satisfied at work, while those workers who perceive themselves as not very capable will see their affective job satisfaction diminished.

As regards the relationships between perceived physical and mental work ability and the three dimensions of work-health balance, our results indicate that perceived physical work ability is negatively associated with WHI and positively associated with HC, while perceived mental work ability is only significantly (and negatively) associated with WHI. These results partially confirm our second and third hypotheses. It is important to note that, in both cases, the intrinsic dimension of the work-health balance construct, i.e. the self-assessed balance or imbalance between the worker's own capacities and the requirements of their job, was found to be significant. This dimension is closely linked to perceived work ability, which is itself mainly a question of balance between job demands (physical and/or mental) and the worker's individual resources. These results indicate that perceived work ability is an antecedent of WHI and HC. Thus, a higher capacity will determine less incompatibility between work and health and a more positive evaluation of management.

Similarly, the results regarding the relationship between the three dimensions of work-health balance and affective job satisfaction revealed two associations: a negative link between affective job satisfaction and WHI and a positive link between affective job satisfaction and HC. This only partially confirms our fourth hypothesis. Our results are consistent with those reported by other studies exploring the relationship between the different dimensions of work-health balance and affective job satisfaction (Gragnano et al., 2017, 2020; Miglioretti \& Gragnano, 2017), although it should be noted that Gragnano et al. $(2017,2020)$ only used a single item to measure affective job satisfaction. We found similar correlations using the BIAJS. Furthermore, Miglioretti and Gragnano (2017) and Gragnano et al. (2020) did not use the WHI, HC and ES dimensions, but rather worked with a single index of the work-health balance construct. Our results show that WHI and $\mathrm{HC}$ are antecedents of affective job satisfaction, so those workers who perceive that their work is incompatible with their health will be less satisfied at work. In the same way, when 
the performance of management is positively evaluated in terms of their interest in the health of workers, they experience better affective job satisfaction.

Finally, our data confirm that the HC and WHI dimensions of the work-health balance construct mediate the relationship between perceived physical and mental work ability and affective job satisfaction. The ES dimension was not found to be significant in either case. It is worth remembering that this dimension refers, among other aspects, to scheduling flexibility and the support of the supervisor, and that recent studies have concluded that both aspects improve affective job satisfaction (Johnson \& Johnson, 2020; Li et al., 2020; Sharkey \& Caska, 2020; Winoto et al., 2021). However, in our study, this relationship was not clearly observed, perhaps because ES is not the same construct as job flexibility or perceived support, representing the help perceived as potentially available in the workplace that can be used in case of health needs (Gragnano et al., 2017). Therefore, the marginal role of ES in our study may be because the sample was not characterized by health problems.

In short, our results show that a better perceived work capacity will increase affective job satisfaction, and that this will depend in part on the perception that the worker has of the compatibility between their work and their health, as well as their perception of the interest that show the hierarchical superiors of the company in the health of the employees. This implies that showing concern for the health of employees by management could improve employee satisfaction. Thus, workers with a reduced perceived work capacity could benefit from this fact. Additionally, providing resources so that job requirements are not perceived as incompatible with health would improve affective job satisfaction. In this sense, it is necessary to continue investigating how to improve this perception of the worker.

\section{Limitations and Future Research}

Our study has certain limitations that should be taken into consideration when interpreting the results. The first is related to the use of self-report measures. Future studies may wish to use objective measures (e.g. health, performance, and absenteeism), as well as the perceptions of supervisors and colleagues, to corroborate whether employee perceptions are in line with real results.

The second limitation is linked to the sample. Our sample was made up of older workers. In this sense, it is important to examine different generations in order to avoid confusion when interpreting the data.

The final limitation is the cross-sectional nature of the research design. The hypothesized causal relationships have to be confirmed in future longitudinal studies.

Despite these limitations, however, our findings open up several different relevant avenues for future research.

Our sample comprised older workers for whom health is often a key aspect of their lives. Other populations for whom health-related issues are particularly important include those with long-standing health problems or disabilities, and 
women returning to work after having children. It has been well-documented that individuals who survive the acute stage of a disease often experience a change in priorities, attaching less importance to work and more to aspects linked to their health and well-being (Hartke et al., 2011). Future studies may wish to explore HC and WHI as a means of predicting affective job satisfaction and worker well-being following their return to work.

There is evidence to suggest that women who work after giving birth have higher rates of respiratory infections, breast-related and gynaecological symptoms, and mental health problems than those who do not work (Baum, 2003; Gjerdingen et al., 1991; Maynard \& Blain, 2005). Moreover, an increase has been observed in depressive symptoms, along with a reduction in general self-reported health and general well-being among women returning to work after maternity leave (Chatterji \& Markowitz, 2012), and due to maternity leave itself, women have higher rates of job mobility than men (Andersen et al., 2008). Future research should focus on HC and WHI as a means of facilitating women's return to work and work retention that, in turn, may help increase their participation in the labour market (Lucia-Casademunt et al., 2018).

Finally, future research should examine the dispositional determinants of WHB. WHB is an indirect and subjective measure and as such must be influenced by personality factors. In this way, the mediating role of WHB could be moderated by aspects such as perceived susceptibility to the disease (Duncan et al., 2009) and other dispositional aspects determining affective job satisfaction (Heller et al., 2009; PujolCols \& Dabos, 2018).

\section{Practical Implications}

The results of our study suggest that HC and WHI mediate the relationship between perceived work ability and affective job satisfaction. Given that affective job satisfaction correlates positively with job performance and negatively with job turnover, HC and WHI may be used to predict affective job satisfaction, job performance and intention to switch jobs, particularly among older workers (as in our study) and other populations for whom health is a key issue, such as those with long-standing health problems or disabilities and women returning to work after maternity leave with some kind of health problem or without having fully recovered their health. However, further studies are required to confirm the predictive utility of these dimensions of the work-health balance construct.

The mediating role of HC and WHI opens up a promising intervention pathway for organizations wishing to increase affective job satisfaction and work retention among older workers or those with health problems. Habeck et al. (2008) carried out a systematic review of the extant literature on work retention among workers with long-standing health problems or disabilities, concluding that the employer practices that resulted in the highest levels of work retention were those designed to satisfy the 
health needs of these employees. Interventions designed to improve HC or WHI may result in lower intention to switch jobs and lower early leaving rates. Nevertheless, further research is required to confirm this hypothesis.

In sum, the information gleaned in relation to the $\mathrm{HC}$ and WHI dimensions may prove useful for different groups and organizations. Governments, for example, may wish to adopt measures to decrease the likelihood of early retirement among older workers and those with health problems. These measures are crucial for guaranteeing the sustainability of the pension system in countries with an ageing population, such as Spain. Companies too may wish to reorganize themselves in order to maintain high levels of productivity among older workers or those with health problems. Finally, trade unions may wish to orient negotiations towards ensuring the conditions necessary to guarantee the health of older workers and those with health problems.

\section{Conclusions}

Due to the current and future situation of the labour market, the situation of older workers is becoming increasingly important. It is vital for governments and states to create the conditions required to foster the affective job satisfaction, well-being and health of this population, particularly in the case of those with health problems. This would guarantee both workers' quality of life and their efficacy in their respective organizations, as well as provide economic stability in a context characterized by an ageing population.

Perhaps following the worldwide health and financial crisis precipitated by the COVID-19 virus and the preventive measures imposed by governments in different countries with the aim of halting the pandemic, the work-health balance construct will become more relevant. In this new context, workers will be more concerned about their health and about preventing illness and will demand that companies provide the resources for protecting their health. It is clear that, in the future, workers will attach even greater importance to the question of how favourably disposed their work environment is to meet their personal health requirements, and how much of an effort their employers are willing to make to satisfy their health needs.

\section{References}

Alcover, C-M., \& Topa, G. (2018). Work characteristics, motivational orientations, psychological work ability and job mobility intentions of older workers. PLoS ONE, 13(4), e0195973. https://doi.org/10.1371/journal. pone.0195973 
Andersen, T., Haahr, J. H., Hansen Eggert, M., \& Holm-Pedersen, M. (2008). Job mobility in the European Union: Optimising its social and economic benefits. Final report. Danish Technological Institute, Centre for Policy and Business Analysis. Retrieved from https://dokumen.tips/reader/f/job-mobility-in-the-european-union-optimising-itssocial-mobility-in-in

Baum, C. L. (2003). Does early maternal employment harm child development? An analysis of the potential benefits of leave taking. Journal of Labor Economics, 21(2), 409-448. https://doi.org/10.1086/345563

Boissonneault, M., \& De Beer, J. (2018). Work ability trajectories and retirement pathways: A longitudinal analysis of older American workers. Journal of Occupational and Environmental Medicine. 60(7), e343-e348. https://doi.org/10.1097/JOM. 0000000000001353

Cantarelli, P., Belardinelli, P., \& Belle, N. (2016). A meta-analysis of job satisfaction correlates in the public administration literature. Review of Public Personnel Administration, 36, 115-144. https://doi.org/10.1177/0734371X15578534

Carsten, J. M., \& Spector, P. E. (1987). Unemployment, job satisfaction, and employee turnover: A meta-analytic test of the Muchinsky model. Journal of Applied Psychology, 72(3), 374-381. https://doi.org/10.1037/0021-9010.72.3.374

Chatterji, P., \& Markowitz, S. (2012). Family leave after childbirth and the mental health of new mothers. Journal of Mental Health Policy and Economics, 15(2), 61-76.

De Zwart, B. C. H., Frings-Dresen, M. H. W., \& Van Duivenbooden, J. C. (2002). Test-retest reliability of the Work Ability Index questionnaire. Occupational Medicine, 52(4), 177181. https://doi.org/10.1093/occmed/52.4.177

Díaz-Bethencourt, A. V., \& Prieto-Morales, M. C. (2016). Relación entre la incapacidad laboral y el uso del Índice de Capacidad de Trabajo. [Relationship between working incapacity and Work Ability Index usage]. Medicina y Seguridad del Trabajo, 62(242), 66-78.

Duncan, L. A., Schaller, M., \& Park, J. H. (2009). Perceived vulnerability to disease: Development and validation of a 15-item self-report instrument. Personality and Individual Differences, 47(6), 541-546. https://doi.org/10.1016/j.paid.2009.05.001

European Statistical Office. (2011). Population by type of disability, sex, age and labour status. Retrieved from https://appsso.eurostat.ec.europa.eu/nui/show.do?dataset= hlth_dlm040\&lang=en

Fernández-Muñoz, J. J., \& Topa, G. (2018). Older workers and affective job satisfaction: Gender invariance in Spain. Frontiers in Psychology, 9, 930. https://doi.org/10.3389/ fpsyg.2018.00930

Figueredo, J. M., García-Ael, C., Gragnano, A., \& Topa, G. (2020). Well-being at work after return to work (rtw): A systematic review. International Journal of Environmental Research and Public Health, 17(20), 7490. https://doi.org/10.3390/ijerph17207490 
Fisher, G. G., Bulger, C. A., \& Smith, C. S. (2009). Beyond work and family: A measure of work/nonwork interference and enhancement. Journal of Occupational Health Psychology, 14, 441-456. https://psycnet.apa.org/doi/10.1037/a0016737

Gjerdingen, D. K., Froberg, D. G., \& Kochevar, L. (1991). Changes in women's mental and physical health from pregnancy through six months postpartum. The Journal of Family Practice, 32(2), 161-166.

Gragnano, A., Miglioretti, M., Frings-Dresen, M. H. W., \& de Boer, A. G. E. M. (2017). Adjustment between work demands and health needs: Development of the WorkHealth Balance Questionnaire. Rehabilitation Psychology, 62(3), 374-386. https://psycnet.apa.org/doi/10.1037/rep0000121

Gragnano, A., Previtali, F., Manzi, C., \& Miglioretti, M. (2018, August 30-September 1). Investigating work-health balance in railway older employees: Results of a LPA. [Paper presentation]. II International Conference on Healthier societies fostering healthy organizations: A cross-cultural perspective, Florence, Italy. https://doi.org/10.13140/ RG.2.2.24500.30084

Gragnano, A., Simbula, S., \& Miglioretti, M. (2020). Work-life balance: Weighing the importance of work-family and work-health balance. International Journal of Environmental Research and Public Health, 17(3), 907. https://doi.org/10.3390/ ijerph17030907

Grant-Vallone, E. J., \& Ensher, E. A. (2001). An examination of work and personal life conflict, organizational support, and employee health among international expatriates. International Journal of Intercultural Relations, 25, 261-278. https://doi.org/10. 1016/S0147-1767(01)00003-7

Habeck, R., Yasuda, S., Rachel, C., \& Kregel, J. (2008). Organizational factors that facilitate successful job retention of employees with health impairments and disabilities. In P. Wehman, J. Kregel, \& V. Brooke (Eds.), Workplace supports and job retention: Promoting an employer driven approach to employment of people with disabilities (pp. 39-66). The Virginia Commonwealth University Rehabilitation Research and Training on Workplace Supports and Job Retention.

Hartke, R. J., Trierweiler, R., \& Bode, R. (2011). Critical factors related to return to work after stroke: A qualitative study. Topics in Stroke Rehabilitation, 18(4), 341-351. https://doi.org/10.1310/tsr1804-341

Hayes, A. F. (2009). Beyond Baron and Kenny: Statistical mediation analysis in the new millennium. Communication Monographs. https://doi.org/10.1080/03637750903310360

Hayes, A. F., \& Preacher, K. J. (2013). Conditional process modeling: Using structural equation modeling to examine contingent causal processes. In G. R. Hancock \& R. O. Mueller (Eds.), Quantitative methods in education and the behavioral sciences: Issues, research, and teaching. Structural equation modeling: A second course (pp. 219-266). IAP Information Age Publishing.

Heller, D., Ferris, D. L., Brown, D., \& Watson, D. (2009). The influence of work personality on job satisfaction: Incremental validity and mediation effects. Journal of Personality, 77(4), 1051-1084. https://doi.org/10.1111/j.1467-6494.2009.00574.x 
Hochwarter, W. A., Perrewé, P. L., Ferris, G. R., \& Brymer, R. A. (1999). Job satisfaction and performance: The moderating effects of value attainment and affective disposition. Journal of Vocational Behavior, 54(2), 296-313. https://doi.org/10.1006/jvbe.1998.1659

Huffman, A. H., Youngcourt, S. S., Payne, S. C., \& Castro, C. A. (2008). The importance of construct breadth when examining interrole conflict. Educational and Psychological Measurement, 68, 515-530. https://doi.org/10.1177\%2F0013164407308472

Hughes, E. L., \& Parkes, K. R. (2007). Work hours and well-being: The roles of work-time control and work-family interference. Work \& Stress, 21, 264-278. https://doi.org/10.1080/02678370701667242

Hurtado, D. A., Kim, S. S., Subramanian, S. V., Dennerlein, J. T., Christiani, D. C., Hashimoto, D. M., \& Sorensen, G. (2017). Nurses' but not supervisors' safety practices are linked with job satisfaction. Journal of Nursing Management, 25, 491-497. https://doi.org/10.1111/jonm.12484

Ilmarinen, J. (2005). Towards a longer worklife: Ageing and the quality of worklife in the European Union. Finnish Institute of Occupational Health, Ministry of Social Affairs and Health.

Johnson, D. S., \& Johnson, A. D. (2020). Perceived leadership support of work-life programs and job satisfaction in the federal government. Review of Integrative Business and Economics Research, 10(4), 47-57.

Judge, T. A., Bono, J. E., Thoresen, C. J., \& Patton, G. K. (2001). The job satisfaction-job performance relationship: A qualitative and quantitative review. Psychological Bulletin, 127(3), 376-402. https://doi.apa.org/doi/10.1037/0033-2909.127.3.376

Judge, T. A., Weiss, H. M., Kammeyer-Mueller, J. D., \& Hulin, C. L. (2017). Job attitudes, job satisfaction, and job affect: A century of continuity and of change. Journal of Applied Psychology, 102, 356-374. https://doi.org/10.1037/apl0000181

Kalliath, T., \& Brough, P. (2008). Work-life balance: A review of the meaning of the balance construct. Journal of Management \& Organization, 14, 323-327. https://doi.org/10. 5172/jmo.837.14.3.323

Keeney, J., Boyd, E. M., Sinha, R., Westring, A. F., \& Ryan, A. M. (2013). From "workfamily" to "work-life": Broadening our conceptualization and measurement. Journal of Vocational Behavior, 82, 221-237. https://doi.org/10.1016/j.jvb.2013.01.005

Kottwitz, M. U., Hünefeld, L., Frank, B. P., \& Otto, K. (2017). The more, the better? Multiple vs. single jobholders' job satisfaction as a matter of lacked information. Frontiers in Psychology, 8, 1274-1285. https://doi.org/10.3389/fpsyg.2017.01274

Li, X., Zhang, Y., Yan, D., Wen, F., \& Zhang, Y. (2020). Nurses' intention to stay: The impact of perceived organizational support, job control and job satisfaction. Journal of Advanced Nursing, 76, 1141-1150. https://doi.org/10.1111/jan.14305

Lingard, H., Brown, K., Bradley, L., Bailey, C., \& Townsend, K. (2007). Improving employees' work-life balance in the construction industry: Project alliance case study. Journal of Construction Engineering and Management, 133, 807-815. https://doi.org/10.1061/(ASCE)0733-9364(2007)133:10(807) 
Locke, E. A. (1969). What is job satisfaction? Organizational Behavior and Human Performance, 4, 309-336. https://doi.org/10.1016/0030-5073(69)90013-0

Lucia-Casademunt, A. M., García-Cabrera, A. M., Padilla-Angulo, L., \& Cuéllar-Molina, D. (2018). Returning to work after childbirth in Europe: Well-being, work-life balance, and the interplay of supervisor support. Frontiers in Psychology, 9, 68. https://doi.org/10.3389/fpsyg.2018.00068

Marqueze, E. C, \& de Castro, C. R. (2009). Satisfação no trabalho e capacidade para o trabalho entre docentes universitários. [Job satisfaction and work ability among college educators]. Psicologia em Estudo, 14(1), 75-82. https://doi.org/10.1590/S141373722009000100010

Martínez, M. C., \& Latorre, M. (2006). Saúde e capacidade para o trabalho em trabalhadores de área administrativa. [Health and work ability among office workers]. Revista de Saúde Pública, 40(5), 851-858. https://doi.org/10.1590/S0034-89102006000600015

Martínez, M. C., Paraguay, A. I., \& Latorre, M. (2004). Relação entre satisfação com aspectos psicossociais e saúde dos trabalhadores [Relationship between psychosocial job satisfaction and health in white collar workers]. Revista de Saude Publica, 38(1), 5561. https://doi.org/10.1590/s0034-89102004000100008

Mateo-Rodríguez, I., Ranchal, A., Oliver, C., Queralto, N., Daponte, A., \& Miembros equipo sTAR (2019, October 3-4). Validación del Índice de Capacidad laboral en profesionales del sector salud mayores de 45 años. [Validation of the Work Capacity Index in health sector professionals over 45 years of age]. [Paper presentation]. II Congress Prevent: From Theory to Practice, Madrid, Spain. Retrieved from https://prevencionar.com/2020/01/16/validacion-del-indice-de-capacidad-laboral-enprofesionales-del-sector-salud-mayores-de-45-anos/

Maynard, S. A., \& Blain, L. G. (2005). Women, work and childcare: Where have we been? Where are we going? Work, 24(4), 361-367.

McGonagle, A. K., Fisher, G. G., Barnes-Farrell, J. L., \& Grosch, J. W. (2015). Individual and work factors related to perceived work ability and labor force outcomes. Journal of Applied Psychology, 100(2), 376-398. https://doi.org/10.1037/a0037974

Miglioretti, M., \& Gragnano, A. (2016). Subjective well-being and health in organizations. Psicologia della Salute, 1, 44-48, https://doi.org/10.3280/PDS2016-001006

Miglioretti, M., \& Gragnano, A. (2017, May 26-27). Work-health balance: Reconciliation between health and work in Italian companies. [Paper presentation]. Healthier society fostering healthy organizations, Florence, Italy.

Moorman, R. H. (1993). The influence of cognitive and aff ective based job satisfaction measures on the relationship between satisfaction and organizational citizenship behavior. Human Relations, 46, 759-776. https://doi.org/10.1177\%2 F001872679304600604

Morschhäuser, M., \& Sochert, R. (2006). Healthy work in an ageing Europe. Strategies and instruments for prolonging working life. Federal Association of Company Health Insurance Funds. 
Myers, R. H. (1990). Classical and modern regression with applications (Vol. 2). Duxbury Press.

O’Driscoll, M. P., Ilgen, D. R., \& Hildreth, K. (1992). Time devoted to job and off-job activities, interrole conflict, and affective experiences. Journal of Applied Psychology, 77, 272-279. https://doi.org/10.1037/0021-9010.77.3.272

Peralta, N., Godoi Vasconcelos, A. G., Härter Griep, R., \& Miller, L. (2012). Validez y confiabilidad del Índice de Capacidad para el Trabajo en trabajadores del primer nivel de atención de salud en Argentina [Validity and reliability of the Work Ability Index in primary care workers in Argentina]. Salud Colectiva, 8(2), 163-173. https://doi.org/10.1590/S1851-82652012000200005

Pinayungan Dongoran, A., Nazaruddin, \& Purnomo Wibowo, R. (2020). Analysis of effect of leadership style, work motivation and work ability to employee satisfaction in increasing performance of harvesters. IOP Conference Series: Materials Science and Engineering, 801, 012073. https://doi.org/10.1088/1757-899X/801/1/012073

Previtali, F., Gragnano, A., \& Miglioretti, M. (2018, August 30 - September 1). The impact of work-health balance on aging blue-collar employees in the steel industry. [Paper presentation]. II International Conference Healthier societies fostering healthy organizations: A cross-cultural perspective, Florence, Italy. https://doi.org/10.13140/ RG.2.2.27850.00969

Prins, R. (2013). Sickness absence and disability: An international perspective. In P. Loisel \& J. Anema (Eds.), Handbook of work disability: Prevention and management (pp. 3-14). Springer. https://doi.org/10.1007/978-1-4614-6214-9_1

Puigmitja, I., Robledo, E., \& Topa, G. (2019). Cross-cultural validity and psychometric properties of the ISC Intrapreneurial Self-Capital Scale in Spain. Personality and Individual Differences, 151. https://doi.org/10.1016/j.paid.2019.02.040

Pujol-Cols, L. J., \& Dabos, G. E. (2018). Satisfacción laboral: Una revisión de la literatura acerca de sus principales determinantes. [Job satisfaction: A literature review of its main antecedents]. Estudios Gerenciales, 34(146), 3-18. https://dx.doi.org/10.18046/j. estger.2018.146.2809

Radkiewicz, P., \& Widerszal-Bazyl, M. (2005). Psychometric properties of Work Ability Index in the light of comparative survey study. International Congress Series, 1280. https://doi.org/10.1016/j.ics.2005.02.089

Rahsa, S. A., Farida, U., \& Hartono, S. (2020). The Influence of job stress, work ability and leadership style on employee job satisfaction. Journal of Performance Human Resources, 1(1), 33-42.

Randall, M., \& Scott, W. A. (1988). Burnout, job satisfaction, and job performance. Australian Psychologist, 23(3), 335-347. https://doi.org/10.1080/00050068808255616

Saber, D. A. (2014). Frontline registered nurse job satisfaction and predictors over three decades: A meta-analysis from 1980 to 2009. Nursing Outlook, 62, 402-414. https://doi.org/10.1016/j.outlook.2014.05.004 
Sharkey, J., \& Caska, B. (2020). Work-life balance versus work-life merge: A comparative and thematic analysis of workplace well-being. DBS Business Review, 3, 3-72. https://doi.org/10.22375/dbr.v3i0.59

Shore, L. M., \& Martin, H. J. (1989). Job satisfaction and organizational commitment in relation to work performance and turnover intentions. Human Relations, 42(7), 625638. https://doi.org/10.1177\%2F001872678904200705

Siegel, P. A., Post, C., Brockner, J., Fishman, A. Y., \& Garden, C. (2005). The moderating influence of procedural fairness on the relationship between work-life conflict and organizational commitment. Journal of Applied Psychology, 90, 13-24. https://doi.org/10.1037/0021-9010.90.1.13

Silva, A. A., Marqueze, E. C., Rotenberg, L., Fischer, F. M., \& Moreno, C. R. C. (2012). Shift workers in electrical systems control rooms: Job satisfaction and work ability. Sleep Science, 5(2), 49-55.

Söderbacka, T., Nyholm, L., \& Fagerström, L. (2020). Workplace interventions that support older employees' health and work ability - a scoping review. BMC Health Services Research, 20(1), 472. https://doi.org/10.1186/s12913-020-05323-1

Spector, P. E. (1997). Job Satisfaction: Application, assessment, causes, and consequences. Sage.

Sullivan, S. E., \& Bhagat, R. S. (1992). Organizational stress, job satisfaction and job performance: Where do we go from here? Journal of Management, 18(2), 353-374. https://doi.org/10.1177\%2F014920639201800207

Thompson, E. R., \& Phua, F. T. T. (2012). A brief index of aff ective job satisfaction. Group \& Organization Management, 37, 275-307. https://doi.org/10.1111/opn.12147

Trifoglio, V. (2018). Connections between resilience, work-related factors and perceived organisational practices - Focus on older Finnish nurses [Unpublished master's thesis]. University of Tampere.

Tuomi, K., Ilmarinen, J., Jahkola, A., Katajarinne, L., \& Tulkki, A. (1998). Work Ability Index (2nd ed.). Finnish Institute of Occupational Health.

Winoto, H., Tecualu, M., \& Wijaya, S. (2021). The effect of compensation and supervisor support mediated by job satisfaction on employee retention (case study at PT Pradu). Primanomics: Jurnal Ekonomi \& Bisnis, 19(1), 147-157. https://doi.org/10.31253/ pe.v19i1.513

World Health Organization. (2002). World health report 2002: Reducing risks, promoting healthy life; overview. https://apps.who.int/iris/handle/10665/67454 


\title{
Medijacijska uloga ravnoteže između posla i zdravlja u odnosu između percipirane radne sposobnosti i afektivnoga zadovoljstva poslom
}

\begin{abstract}
Sažetak
Sve kasnija dob odlaska u mirovinu mogla bi rezultirati većim brojem zaposlenika sa zdravstvenim problemima. Taj je podatak važan jer je zdravlje ključan element svih aspekata života, uključujući i zaposlenje. Iako su mnoga istraživanja ispitivala utjecaj ravnoteže između posla i života na zdravlje na radnome mjestu, mali se broj istraživanja usmjerio na ispitivanje utjecaja sposobnosti za balansiranje zdravstvenih potreba i radnih zadataka (ravnotežu između posla i zdravlja) na različite organizacijske varijable poput percipirane radne sposobnosti i afektivnoga zadovoljstva poslom. U uvjetima u kojima je dob umirovljenja u stalnome porastu ključno je ispitati čimbenike koji bi mogli pomoći u produljenju čovjekova radnoga vijeka na uravnotežen način. Stoga je cilj ovoga istraživanja bio istražiti medijacijsku ulogu ravnoteže između posla i zdravlja u odnosu između percipirane radne sposobnosti (mentalne i tjelesne) i afektivnoga zadovoljstva poslom. Korištenjem kros-sekcijskoga uzorka od 294 zaposlenika iznad 39 godina starosti u istraživanju je analizirana medijacijska uloga različitih dimenzija ravnoteže između posla i zdravlja (zdravstvena klima, nekompatibilnost posla i zdravlja te vanjska podrška) u odnosu između radne sposobnosti (mentalne i tjelesne) te afektivnoga zadovoljstva zdravljem. Podaci pokazuju da su zdravstvena klima i nekompatibilnost posla i zdravlja medijatori odnosa između percipirane radne sposobnosti (mentalne i tjelesne) i afektivnoga zadovoljstva poslom. Dobiveni su nalazi u skladu s trenutačnim razumijevanjem uloge koju ima ravnoteža između zdravlja na radnome mjestu i dobrobiti starijih zaposlenika.
\end{abstract}

Ključne riječi: ravnoteža između posla i zdravlja, percipirana radna sposobnost, afektivno zadovoljstvo poslom, zadržavanje zaposlenja, stariji zaposlenici

Primljeno: 14. 4. 2021. 